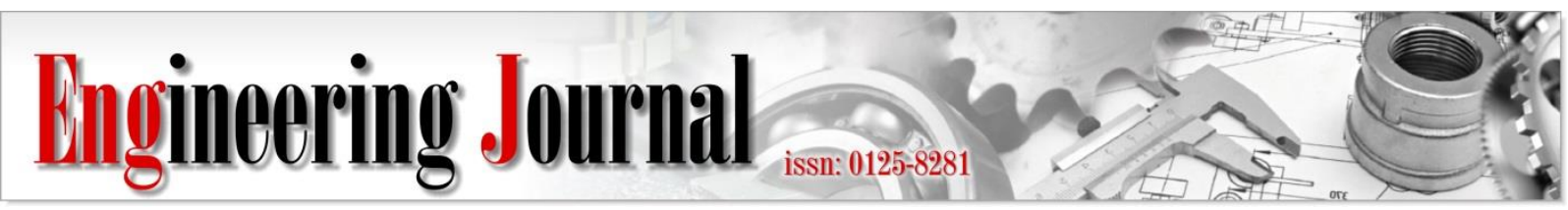

Article

\title{
Relationship between Land Surface Temperature and Land Use in Nakhon Ratchasima City, Thailand
}

\author{
Pakawan Chotchaiwong ${ }^{1, a}$ and Saowanee Wijitkosum ${ }^{2, b, *}$ \\ 1 Department of Environmental Science Graduate School, Faculty of Graduate School, Chulalongkorn \\ University, Phayathai Road, Pathumwan, Bangkok 10330, Thailand \\ 2 Environmental Research Institute, Chulalongkorn University, Institute Building 2, Phayathai Road, \\ Pathumwan, Bangkok 10330, Thailand \\ E-mail: aginkpkwn@gmail.com, bw.m.saowanee@gmail.com (Corresponding author)
}

\begin{abstract}
The relationship between land surface temperature (LST) and land use in Nakhon Ratchasima was studied using data gathered from three satellite images from Landsat-5 (30th January 1992), Landsat-8 (9 May 2016) and THEOS (17th February 2016). There were four categories of land use: built-up area, green area, bare land and water sources. The split-window concept was used to estimate the LST. In 1992, Nakhon Ratchasima city in Thailand comprised $47.76 \%$ built-up area, 37.45\% green area, $13.19 \%$ bare land and $1.60 \%$ water sources. By 2016, the built-up area had increased by $23.04 \%$, the green area had decreased by $16.66 \%$, bare land had decreased by $6.81 \%$, but water sources had increased by $0.43 \%$. Moreover, in 1992 the mean LST was $25.43{ }^{\circ} \mathrm{C}$ for built-up areas, $24.44^{\circ} \mathrm{C}$ for green areas, $24.97{ }^{\circ} \mathrm{C}$ for bare land and $24.75^{\circ} \mathrm{C}$ for water sources. However, by 2016 the LSTs had increased for each category: $28.74{ }^{\circ} \mathrm{C}$ for built-up areas $\left(+3.31{ }^{\circ} \mathrm{C}\right)$, $27.20^{\circ} \mathrm{C}$ for green areas $\left(+2.76^{\circ} \mathrm{C}\right), 28.11^{\circ} \mathrm{C}$ for bare land $\left(+3.14^{\circ} \mathrm{C}\right)$ and $27.72{ }^{\circ} \mathrm{C}$ for water sources $(+2.97$ $\left.{ }^{\circ} \mathrm{C}\right)$. The findings indicated that the LSTs increased with the pace of urbanization and changes in land use. Linear regression analysis revealed that built-up land had a positive correlation with LST, where a $1 \%$ increase in built-up area increased its LST by $0.146594{ }^{\circ} \mathrm{C}$.
\end{abstract}

Keywords: Land surface temperature, land use, urbanization, climate change, urban planning.

ENGINEERING JOURNAL Volume 23 Issue 4

Received 27 September 2018

Accepted 3 April 2019

Published 8 August 2019

Online at http://www.engj.org/

DOI:10.4186/ej.2019.23.4.1 


\section{Introduction}

Urbanization affects the environment at the global scale and can especially increase problems associated with climate change [1-3]. At the local level urbanization causes direct environmental problems, including city drainage, air and water pollution [4], excessive and wasteful usage of natural resources [5], reductions in green areas [6-7] and higher land surface temperatures [1, 8-9]. These factors contribute to the phenomenon known as the urban heat island (UHI). UHI is linked to city power consumption $[3,10]$, and thus affects local and global climate change $[1,11-12]$. Land Surface Temperature (LST) is a critical factor that determines air temperature in the lower layers of the atmosphere, [13-22]. The LST is a key factor for the study of urban air temperatures and has been instrumental in characterizing the emerging phenomenon of the Urban Heat Island (UHI) [23-30].

The LST is calculated from the reflection and radiation of objects on the Earth's surface [10] and so represents the Earth's surface heat. It can be measured using remote sensing images using satellite infrared wave detection. The estimated LST depends on the albedo, ground cover plants and soil humidity [10, 3134]. Most objects in urban areas are buildings with high surface albedo, where reflection depends on construction materials. In addition, urban activity uses much more energy than rural activities, including transportation and building energy consumption [11, 35-36], driving higher temperatures in urban environments.

The relationship between urbanization and LST has been widely studied, e.g. [1, 29, 37-38] and UHI e.g. $[2,30,39-40]$. The topic has also been studied in Thailand, e.g. using remote sensing technology from satellite imagery to assess the UHI in large cities where large changes in land utilization have occurred, including Bangkok [41-45], Chiang Mai [43,46], Songkhla [43] and Mahasarakram [16]. However, Nakhon Ratchasima has not been studied, despite its rapid urbanization and major changes in land utilization. Changes in LST were therefore analyzed and used as a basis for predicting or the effects of urban expansion and changes in land use, which need to be considered in urban development plans in order to prevent or mitigate future environmental problems, and also to monitor and consider introduction of preventive measures [11-12].

The city of Nakhon Ratchasima is the regional centre of northeastern Thailand, largely due to its location. In 1977 government policy designated the city as a 'center of prosperity' to boost the regional economy as part of its decentralization agenda. Nakhon Ratchasima is now one of the country's three fastest expanding cities [5] in terms of both its economy and population density $\left(3,500\right.$ peoples $/ \mathrm{km}^{2}$, excluding the estimated $22 \%$ of the domiciled population who are unregistered [47]. Increasing construction of buildings and roads for businesses and housing has encroached on surrounding green areas and agricultural land [5]. Urban temperatures are increasing; from 1951 to 2018 the mean day and night temperatures were $34^{\circ} \mathrm{C}$ and $24^{\circ} \mathrm{C}$, respectively. Today Nakhon Ratchasima city is the region's largest city and the fifth largest in Thailand. Continuing government promotion of the city as an economic centre and logistic hub is encouraging both horizontal and vertical urban expansion, with taller, larger buildings, and loss of green areas. Increasing energy demand contributes to increased emissions of greenhouse gases and climate change impacts.

Accordingly, the current study of land use patterns and analysis of their impact on Nakhon Ratchasima's LST applied remote sensing technology, including Landsat-5 (30th January 1992), Landsat-8 (9th May 2016) and THEOS (17 th February 2016)satellites. The interpretation identified different categories of land use through supervised classification using the ENVI programme. Land surface temperature in the thermal infrared band shown on the images was interpreted using the split window technique. This method led to the analysis of land surface temperature for each land use type. The data provide an important basis to inform planning future land use and urban expansion to minimize or prevent further increases in LST and mitigate climate change impacts.

\section{Materials and Methods}

\subsection{Study Area}

The study area $\left(37.5 \mathrm{~km}^{2}\right)$ (Fig. 1) covered Nakhon Ratchasima city, located in the Muang Nakhon Ratchasima district, between $14-16^{\circ} \mathrm{N}$ (latitude) and $101-103^{\circ} \mathrm{E}$ (longitude) at approximately $174-206 \mathrm{~m}$ above mean sea level. The terrain around the city consists of a plain in the north, which has a flooding problem in some areas, a high hill in the south that is connected to a military base and the national conserved forest, a plateau to the 
west and a basin in the east. The Lam Ta Kong River flows through the city for a total $12 \mathrm{~km}$ of the river's length; the river banks were formerly major agricultural areas [7].

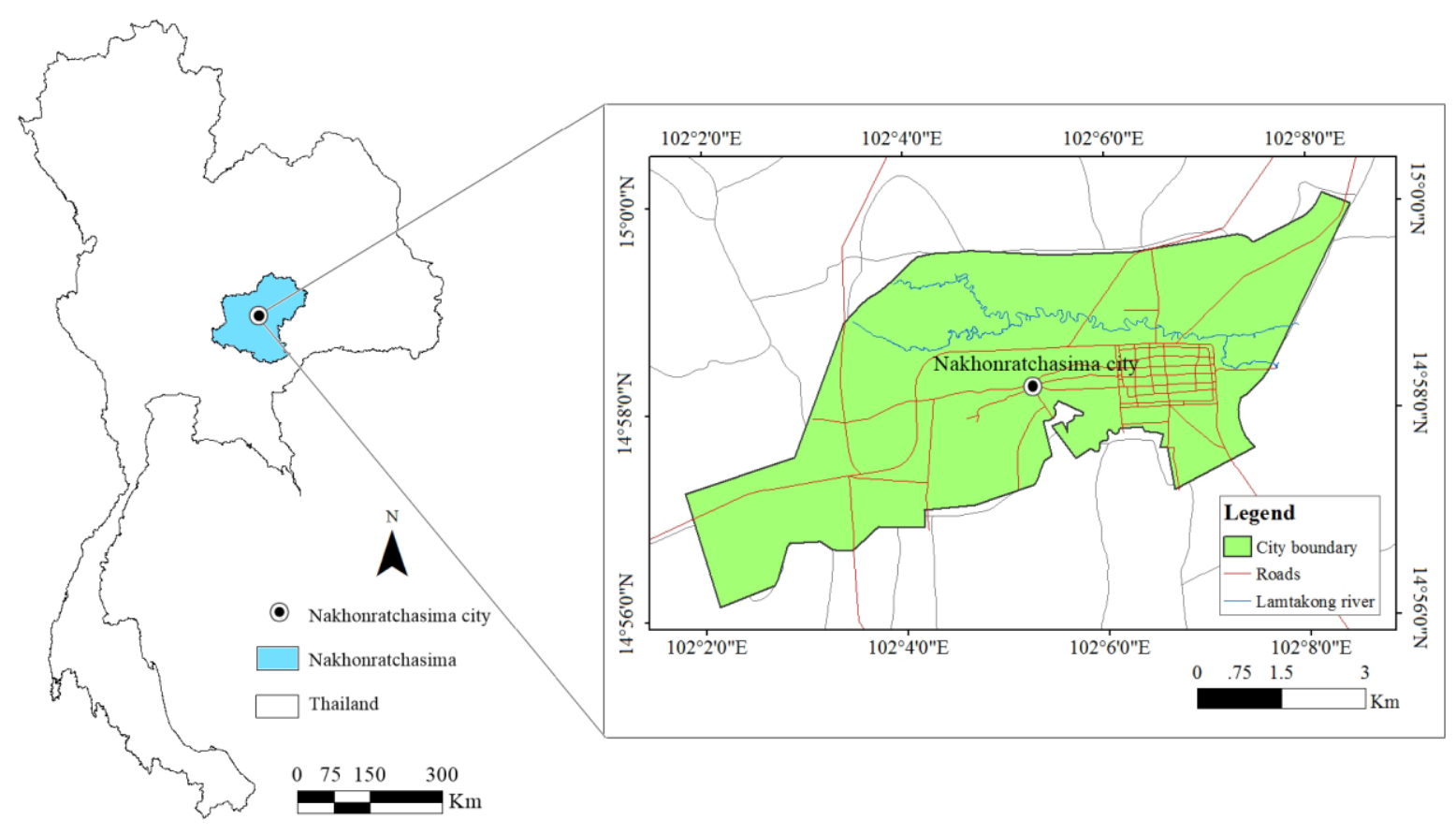

Fig. 1. Nakhon Ratchasima City Territories.

However, Nakhon Ratchasima's weather in the past 30 years (1985-2014), obtained from Nakhon Ratchasima Meteorological Station [48], reported that the average was $27.46^{\circ} \mathrm{C}$ Celsius. The highest temperature was in April $\left(30^{\circ} \mathrm{C}\right.$ Celsius) and lowest in December $\left(23.9^{\circ} \mathrm{C}\right.$ Celsius). Average land surface temperature was $21.07^{\circ} \mathrm{C}$ Celsius which was the highest in September $\left(23.52^{\circ} \mathrm{C}\right.$ Celsius $)$ and lowest in December $\left(16.64^{\circ} \mathrm{C}\right.$ Celsius). The wind speed was 2.01 knot. The average evaporation rate was $4.85 \mathrm{~mm}$ per day and reached $5.6 \mathrm{~mm}$ in the dry season.

\subsection{Evaluation of Land Usage}

The land usage was evaluated by interpreting satellite images [6, 49], Landsat-5TM (30th January 1992; at 09.55 am) using a thematic mapper system at 30-m image resolution and THEOS (17 th February 2016; at $10.26 \mathrm{am}$ ) with a Multispectral 15-m image resolution, using the ENVI programme by supervised classification and digital number $(\mathrm{DN})$ with maximum likelihood analysis. Even though the satellite imagery were derived from different sources, their resolution is sufficiently high to be used to study land utilization in urban areas [4955]. In addition, both images were taken during the same season which is a similar time intervals, and are therefore comparable in terms of light or heating values, which have an impact on classification of image data. The land use data was additionally validated and adjusted by incorporating the geographic information data of the Nakhon Ratchasima municipal government (2016) [56] and field area inspection with more than $90 \%$ confidence [55].

Land usage was divided into four categories based on the USGS Circular 671 [49]: built-up areas (community areas and buildings); green area (agricultural land, forest and rangeland); bare land (wasteland, unused areas); and water sources (natural water sources and built-up water bodies). Some areas (totaling 6.7 $\mathrm{km}^{2}$ ) were omitted because the land use categorization was ambiguous due to the similar reflection of the images such as combined city canal and some water sources. 


\subsection{Evaluation of the LST}

The LST was analyzed using remote sensing images [57] from Landsat-5TM (30th January 1992) and Landsat8 (9 ${ }^{\text {th }}$ May 2016) with thermal infrared band (TIB: Landsat-5 Band 6 and Landsat- 8 Band 10 and 11) from NASA's Earth Observing System using the ENVI programme with the Split window concept. The process is summarized below in Fig. 2.

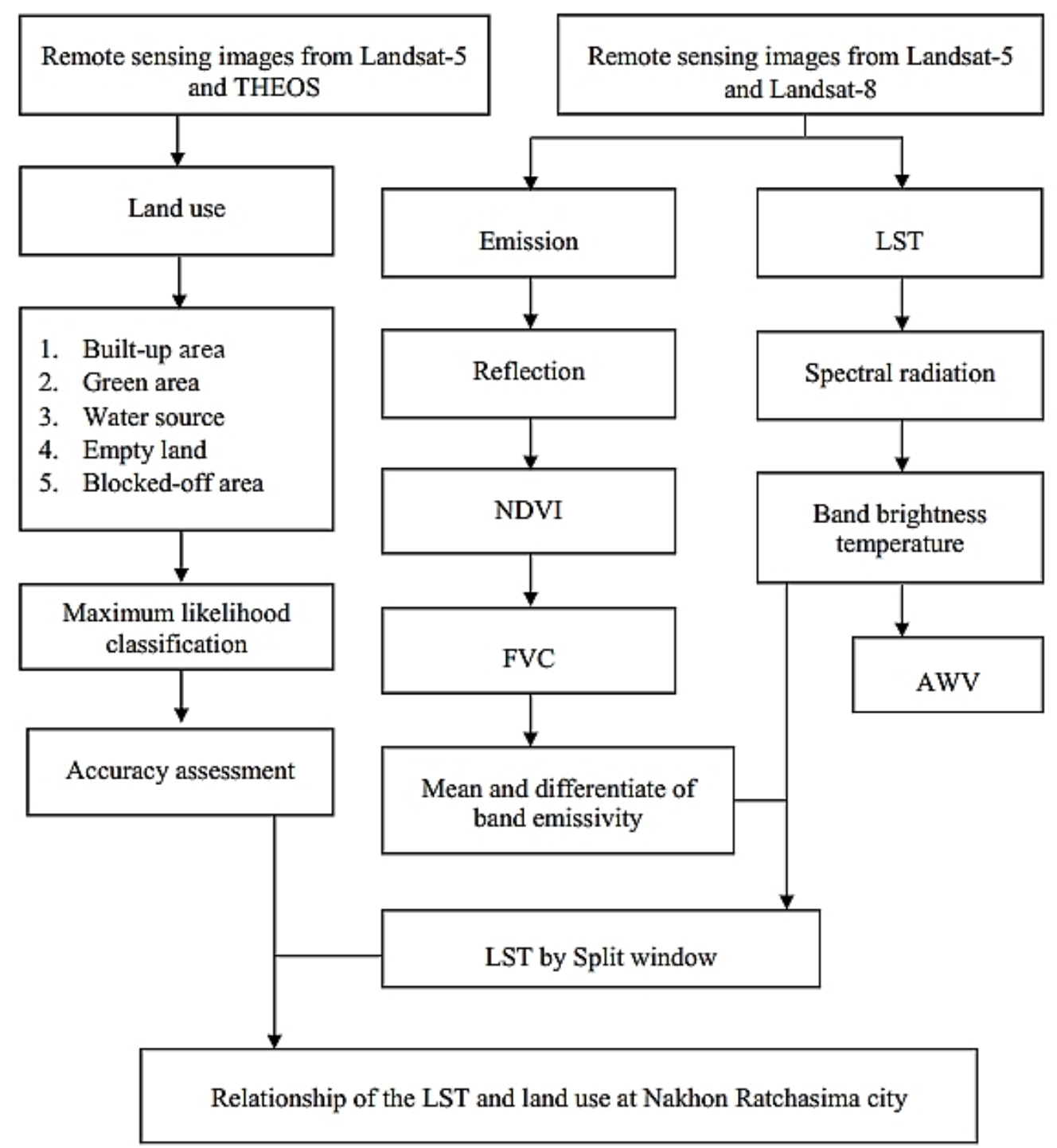

Fig. 2. Methodology, approach and process.

(A) Albedo and LST measurements were correlated and an average relation established. Albedo is a parameter quantitatively describing the absorption/reflection behavior of a surface [58]. The measurement may differ depending on area type, vegetative cover and soil moisture [33-34]. For the brightness temperature, the LST was evaluated from thermal infrared data detected directly from the satellite images. The data could then be converted into degrees Kelvin using Eq. (1); [59]

$$
\mathrm{T}=\frac{\mathrm{K}_{2}}{\ln \left(\frac{\mathrm{K}_{1}}{\mathrm{~L}_{\lambda}}+1\right)},
$$


where $T$ is the effective at-sensor brightness temperature (Kelvin), $K_{2}$ is the calibration constant 2 (Kelvin) (607.76 K for Landsat-5TM Band 6 and $774.8853 \mathrm{~K}, 480.8883 \mathrm{~K}$ for Landsat- 8 Band 10 and 11, respectively), $\mathrm{K}_{1}$ is the calibration constant $1\left(\mathrm{~W} / \mathrm{m}^{2} \mathrm{sr} \mu \mathrm{m}\right)\left(1,260.56 \mathrm{~W} / \mathrm{m}^{2} \mathrm{sr} \mu \mathrm{m}\right.$ for Landsat-5TM Band 6 and $1,321.0789$ $\mathrm{W} / \mathrm{m}^{2}$ sr $\mu \mathrm{m}$ and $1,201.1442 \mathrm{~W} / \mathrm{m}^{2}$ sr $\mu \mathrm{m}$ for Landsat- 8 Band 10 and 11 , respectively), $\mathrm{L}_{\lambda}$ is the spectral radiance at the sensor's aperture $\left(\mathrm{W} / \mathrm{m}^{2} \mathrm{sr} \mu \mathrm{m}\right)$ and $\ln$ is the natural logarithm.

An object's spectral radiance is dependent on wavelength and the ratio between absorbed reflectance and transmittance. Objects with a high absorbance would also have a high radiance, as shown in Eq. (2) [59];

$$
\mathrm{L}_{\lambda}=\left(\frac{L M A X_{\lambda}-L M I N_{\lambda}}{Q_{\text {calmax }}-Q_{\text {calmin }}}\right)\left(Q_{\text {cal }}-Q_{\text {calmin }}\right)+L M I N_{\lambda}
$$

where $L$ is spectral radiance at the sensor's aperture $\left(W / \mathrm{m}^{2} \mathrm{sr} \mu \mathrm{m}\right), \mathrm{Q}_{\text {cal }}$ is quantized calibrated pixel value (DN), $\mathrm{Qc}_{\mathrm{almin}}$ is minimum quantized calibrated pixel value corresponding to $\mathrm{LMIN}_{\lambda}(\mathrm{DN}), \mathrm{Q}_{\text {calmax }}$ is maximum quantized calibrated pixel value corresponding to $\operatorname{LMAX}_{\lambda}(\mathrm{DN}), \mathrm{LMIN}_{\lambda}$ is Spectral at-sensor radiance that is scaled to $Q_{\text {calmin }}\left(\mathrm{W} / \mathrm{m}^{2}\right.$ sr $\left.\mu \mathrm{m}\right)$ and $\operatorname{LMAX}_{\lambda}$ is Spectral at-sensor radiance that is scaled to $\mathrm{Q}_{\text {calmax }}\left(\mathrm{W} / \mathrm{m}^{2} \mathrm{sr} \mu \mathrm{m}\right)[59]$

(B) For the Land Surface Emissivity (LSE), [58] an object's radiation is low compared to the albedo because the Earth's surface cannot absorb all the energy and so the LSE was calculated from the fractional vegetation cover using the differential vegetation index [52], as shown in Eq. (3)

$$
\mathrm{LSE}=\varepsilon_{\mathrm{S}}(1-\mathrm{FVC})+\varepsilon_{\mathrm{V}} \times \mathrm{FVC},
$$

where $\varepsilon \_s$ is the lowest emissivity (1.238 for Landsat-5TM Band 6 and 0.10033 for Landsat- 8 Band 10 and 11), $\varepsilon_{-} v$ is the highest emissivity (15.303 for Landsat- 5 Band 6 and 22.0018 for Landsat- 8 Band 10 and 11) and FVC is the fractional vegetation cover, calculated from the normalized difference in vegetation in each cell, as shown in Eq. (4);

$$
\mathrm{FVC}=\frac{\mathrm{NDVI}-\mathrm{NDVI}_{\mathrm{s}}}{\mathrm{NDVI}_{\mathrm{V}}-\mathrm{NDVI}_{\mathrm{s}}}
$$

where $\mathrm{NDVI}_{\mathrm{V}}$ is the NDVI of vegetation or highest value of NDVI, NDVI $\mathrm{S}$ is the NDVI of soil or lowest value of NDVI and NDVI is the normalized difference vegetation index, derived as shown in Eq. (5) [60];

$$
\text { NDVI }=\frac{\varrho_{\text {NIR }}-\varrho_{\text {RED }}}{\varrho_{\text {NIR }}+\varrho_{\text {RED }}},
$$

where QNIR and QRED are the reflection of vegetation under near infrared and red, respectively, and $\varrho$ is the reflection of soil cover, which depends on wavelength and the ratio of absorbance to reflection. Objects with a high reflection have a low absorbance [59] as shown in Eq. (6);

$$
\varrho_{\lambda}=M_{\varrho} Q_{\text {cal }}+A_{\varrho}
$$

where $\mathrm{M} \_\mathrm{Q}$ is the reflectance multi-band and A_Q is the reflectance add-band.

(C) Atmospheric water vapor (AWV) is a key parameter for the global hydrological cycle, and central to studies of global climate change, land surface-atmosphere energy exchange and watershed management [61]. AWV was determined from the ability to pass through the atmosphere in thermal infrared using the brightness temperature of the linear regression, The AWV was evaluated from thermal infrared data of the Spinning Enhanced Visible and Infrared Imager onboard Meteosat Second Generation satellite (assuming that the atmosphere is unchanged over the neighboring pixels where the land surface temperature and emissivity change). The split-window covariance-variance ratio (SWCVR) method relates AWV to the ratio of the upward transmittances of two thermal infrared bands, as shown in Eq. (7a, 7b);

$$
A W V=(a+b)\left(\frac{\tau_{j}}{\tau_{i}}\right)
$$


and

$$
\frac{\tau_{\mathrm{j}}}{\tau_{\mathrm{i}}} \approx \mathrm{R}_{\mathrm{ji}}=\frac{\sum_{\mathrm{k}=1}^{\mathrm{N}}\left(\mathrm{T}_{\mathrm{i}, \mathrm{k}}-\overline{\mathrm{T}}_{\mathrm{i}}\right)\left(\mathrm{T}_{\mathrm{j}, \mathrm{k}}-\overline{\mathrm{T}}_{\mathrm{j}}\right)}{\sum_{\mathrm{k}=1}^{\mathrm{N}}\left(\mathrm{T}_{\mathrm{i}, \mathrm{k}}-\overline{\mathrm{T}}_{\mathrm{j}}\right)^{2}}
$$

where, $\mathrm{a}$ and $\mathrm{b}$ are coefficients derived from simulation; $\tau$ is the channel effective transmittance; the subscripts $i$ and $j$ represent, respectively, the first and second channels of Thermal InfraRed Sensor (TIRS); $N$ is the number of adjacent pixels (excluding water and cloud pixels) in a window size (i.e., $\mathrm{n} \times \mathrm{n}$ ), Ti,k and Tj,k are the brightness temperatures $(K)$ of the channels $i$ and $j$ for the kth pixel, while $i \mathrm{~T}$ and $j \mathrm{~T}$ are the mean or median brightness temperatures of the $\mathrm{N}$ pixels for the two channels.

Note that, $\tau \mathrm{j} / \tau \mathrm{i}$ is not fully equal to Rji due to the variation of the land cover and emissivity of both $\mathrm{i}$ and j channels for the $\mathrm{N}$ pixels. [61]

(D) The LST was then calculated from the brightness temperature, LSE and AWV as shown in Eq. (8);

$$
\begin{aligned}
& \text { LST }=\left(\mathrm{T}_{10}+\mathrm{C}_{10}-\mathrm{T}_{11}\right)+\left(\mathrm{T}_{10}-\mathrm{T}_{11}\right)^{2} \mathrm{C}_{0}+ \\
& \left(\mathrm{C}_{3}+\mathrm{C}_{4} \mathrm{Wv}\right)(1-\varepsilon)+\left(\mathrm{C}_{5}+\mathrm{C}_{6} \mathrm{AWV}\right) \Delta \varepsilon
\end{aligned}
$$

where $\mathrm{T}_{10}$ and $\mathrm{T}_{11}$ are the brightness temperature of the TIB, $\varepsilon$ is the mean LSE of the TIB, $\Delta \varepsilon$ is the difference in LSE of the TIB, and $\mathrm{C}_{0}$ to $\mathrm{C}_{6}$ are the split window concept constants (the constants remain the same under all conditions) [58] (Table 1).

Table 1. Constants of the split window concept.

\begin{tabular}{llllllll}
\hline Constant & $\mathrm{C}_{1}$ & $\mathrm{C}_{2}$ & $\mathrm{C}_{3}$ & $\mathrm{C}_{4}$ & $\mathrm{C}_{5}$ & $\mathrm{C}_{6}$ & $\mathrm{C}_{7}$ \\
\hline Value & -0.678 & 1.378 & 0.183 & 54.30 & -2.238 & -129.2 & 16.40 \\
\hline
\end{tabular}

\subsection{Relationship of the LST and Land Use}

The relationship between LST and land use was analyzed by randomly selecting 30 points from each land use category to study the characteristics and different LST patterns within each land use category. The data were used to construct a linear regression equation by the least square method [60], as shown in Eq. (9), after calculating the Pearson's correlation coefficient at a statistical significance of $\mathrm{p}<0.01$, as shown in Eq. (10);

$$
\begin{gathered}
r=\frac{n \sum X Y-\sum X \sum Y}{\sqrt{\left[n \sum X^{2}-\left(\sum X\right)^{2}\right]\left[n \sum Y^{2}-\left(\sum Y\right)^{2}\right]}} \\
Y=a+b(X)
\end{gathered}
$$

where $\mathrm{r}$ is the Pearson's correlation coefficient, $\mathrm{Y}$ is the calculated mean LST, $\mathrm{X}$ is the ratio or percentage of urban areas and buildings (calculated during the satellite interpretation process), a is the $\mathrm{Y}$ axis point of intersection and $\mathrm{b}$ is the slope of the equation.

\section{Results}

\subsection{Land Use Pattern in Nakhon Ratchasima City}

Data based on satellite image interpretation showed $92.37 \%$ confidence level and a Kappa Coefficient of 0.89 for 1992; for 2016, the confidence level and Kappa Coefficient were $92.13 \%$ and 0.88, respectively. The largest area of the city was occupied by community settlements and buildings ( $47.76 \%$ of the total area), followed by green areas (37.45\%), bare land (13.19\%) and water bodies (1.60\%) (Fig. 3.). Community settlements and buildings are dispersed throughout the city areas, except for the plateau located in the northeast part of the city, which mainly comprises agricultural areas growing mostly vegetables. Bare land is distributed across the community areas. 
Nakhon Ratchasima has and still is rapidly expanding economically, with a concomitant high degree of urbanization which has brought major changes in land use over the last 24 years. Community settlements and buildings have expanded to cover $70.80 \%$ of the total area $(1.72 \%$ increase p.a.), while the green area has been reduced to only $20.79 \%$ (2.52\% reduction p.a.) and bare land has been reduced to $6.38 \%(3.10 \%$ decrease p.a.) However, water bodies have increased marginally (1.04\% increase p.a.) as shown in Fig. 3.

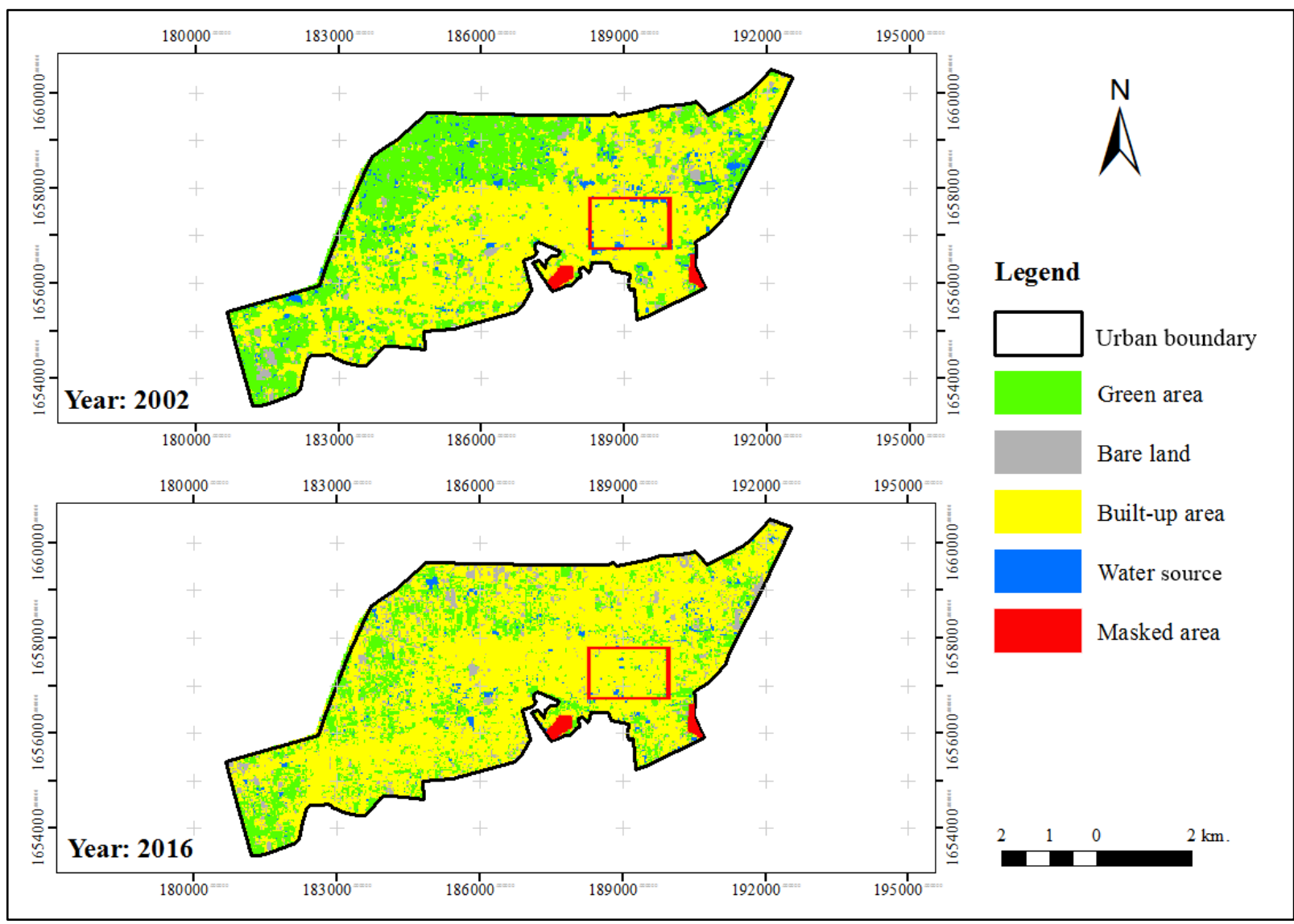

Fig. 3. Land use in Nakhon Ratchasima city between 1992 and 2016.

\subsection{LST of Nakhon Ratchasima City}

Analysis of Nakhon Ratchasima city's LST revealed that on 30 January 1992 it was $24.74{ }^{\circ} \mathrm{C}$, with the mean LST of community settlements and buildings being the highest $\left(25.43^{\circ} \mathrm{C}\right)$, then bare land $\left(24.97^{\circ} \mathrm{C}\right)$, water bodies $\left(24.75^{\circ} \mathrm{C}\right)$ and green areas $\left(24.44^{\circ} \mathrm{C}\right)$ as presented in Table 2 and Fig. 4.

Table 2. Mean and range of LST for each land use category in Nakhon Ratchasima City (1992 and 2016).

\begin{tabular}{|c|c|c|c|c|c|c|}
\hline \multirow{3}{*}{ Land use } & \multicolumn{6}{|c|}{ LST } \\
\hline & \multicolumn{3}{|c|}{1992} & \multicolumn{3}{|c|}{2016} \\
\hline & Maximum & Minimum & Mean & Maximum & Minimum & Mean \\
\hline Built-up area & 27.68 & 23.82 & 25.43 & 31.25 & 27.56 & 28.74 \\
\hline Green area & 25.98 & 22.50 & 24.44 & 28.89 & 25.15 & 27.20 \\
\hline Bare land & 26.83 & 22.94 & 24.97 & 29.74 & 26.68 & 28.11 \\
\hline Water Sources & 26.83 & 22.50 & 24.75 & 29.44 & 25.39 & 27.72 \\
\hline
\end{tabular}

The highest LST $\left(28.10^{\circ} \mathrm{C}\right)$ was located in the old city area, east of the town hall on Mahatthai Road. This area has a high density of residential, commercial and government office buildings and is an important 
commercial and economic hub. Boong Ta Lua Water Park $\left(0.48 \mathrm{~km}^{2}\right)$ had the lowest LST. The water park is the city's main public park and also serves as the main water storage body for the adjacent military base.

Analysis of the city's LST from remote sensing images of Landsat- 8 on 9 May 2016 revealed a $3.30{ }^{\circ} \mathrm{C}$ increase in the mean LST to $28.04{ }^{\circ} \mathrm{C}$ from 1992 to 2016 . Community settlements and buildings had the highest mean LST $\left(28.74{ }^{\circ} \mathrm{C}\right)$, followed by bare land $\left(28.11^{\circ} \mathrm{C}\right)$, water sources $\left(27.72{ }^{\circ} \mathrm{C}\right)$ and green areas $\left(27.20^{\circ} \mathrm{C}\right)$ (Table 2 and Fig. 4).

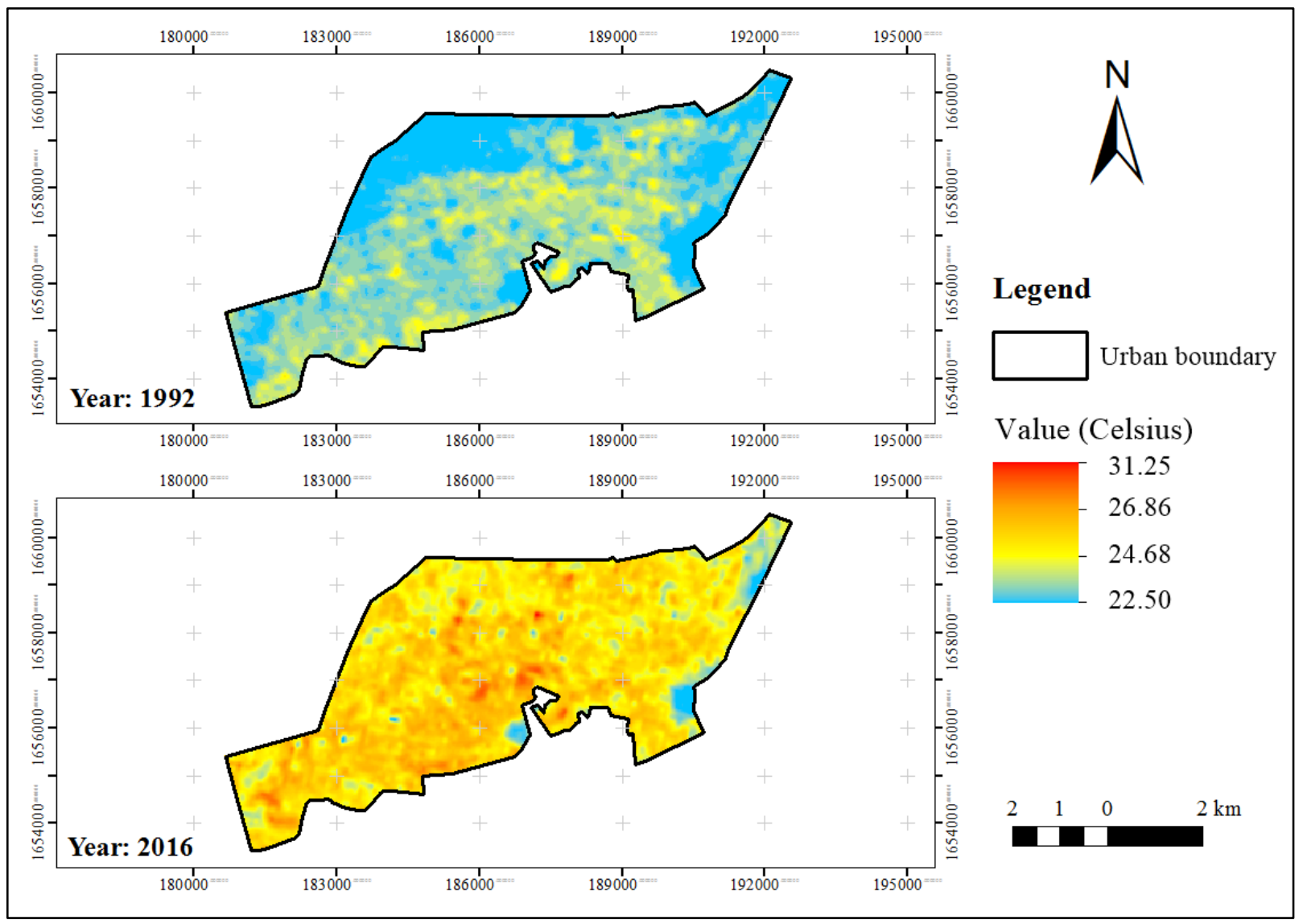

Fig. 4. LST of Nakhon Ratchasima city in 1992 and 2016.

By 2016, the mean LST in the city had increased for all land use categories, compared to 1992 data. Community settlements and buildings showed the highest increases $\left(3.32{ }^{\circ} \mathrm{C}\right)$, followed by a $3.14{ }^{\circ} \mathrm{C}, 2.97^{\circ} \mathrm{C}$, and $2.76^{\circ} \mathrm{C}$ increases for bare land, water sources and green areas, respectively.

When analyzed based on area, the Terminal 21 shopping mall had the highest mean LST $\left(31.25^{\circ} \mathrm{C}\right)$. This is a large shopping mall (approximately $0.05 \mathrm{~km}^{2}$ ) and had a similar LST as high as The Mall, another large shopping mall in the province (approximately $0.09 \mathrm{~km}^{2}$ ). The areas around the municipal government, the building area for the Klang station shopping mall, and east of the petrol station at the north, next to the second transport station of Nakhon Ratchasima city, all had a mean LST of about $31{ }^{\circ} \mathrm{C}$ with the land use in these areas being primarily commercial activities and services, including community settlements and building an immersive new shopping mall. These all reflect the recent rapid economic expansion and development of the city. The lowest mean LST was located at Boong Ta Lua Water Park $\left(22.50^{\circ} \mathrm{C}\right)$.

\subsection{Relationship between LST and Land Use in Nakhon Ratchasima City}

Analysis of the relationship between LST and land use revealed that the community settlements and buildings was highly related to the LST (Pearson's correlation coefficient $=0.8139 ; \mathrm{P}<0.01$ ). These data were used to construct a linear regression equation, shown in Eq. (11). The equation had a coefficient of determination of 0.6625 . 


$$
y=19.09205+0.146597 x
$$

where $\mathrm{x}$ is the built-up area $(\%)$ and $\mathrm{y}$ is the mean LST $\left({ }^{\circ} \mathrm{C}\right)$.

The obtained linear regression between the LST and the changing sizes of community and building areas revealed that the mean LST increased as the proportion of community and building areas increased (Fig. 5). In 2016, community and building areas comprised $70.80 \%$ of the total area with a mean LST of about 29.35 ${ }^{\circ} \mathrm{C}$. If this area is increased to $80 \%$ in the future, the mean LST would be projected to increase to approximately $30.81^{\circ} \mathrm{C}$, or a rate of $0.146597{ }^{\circ} \mathrm{C}$ for every $1 \%$ increase in the ratio of community and building areas to total area.

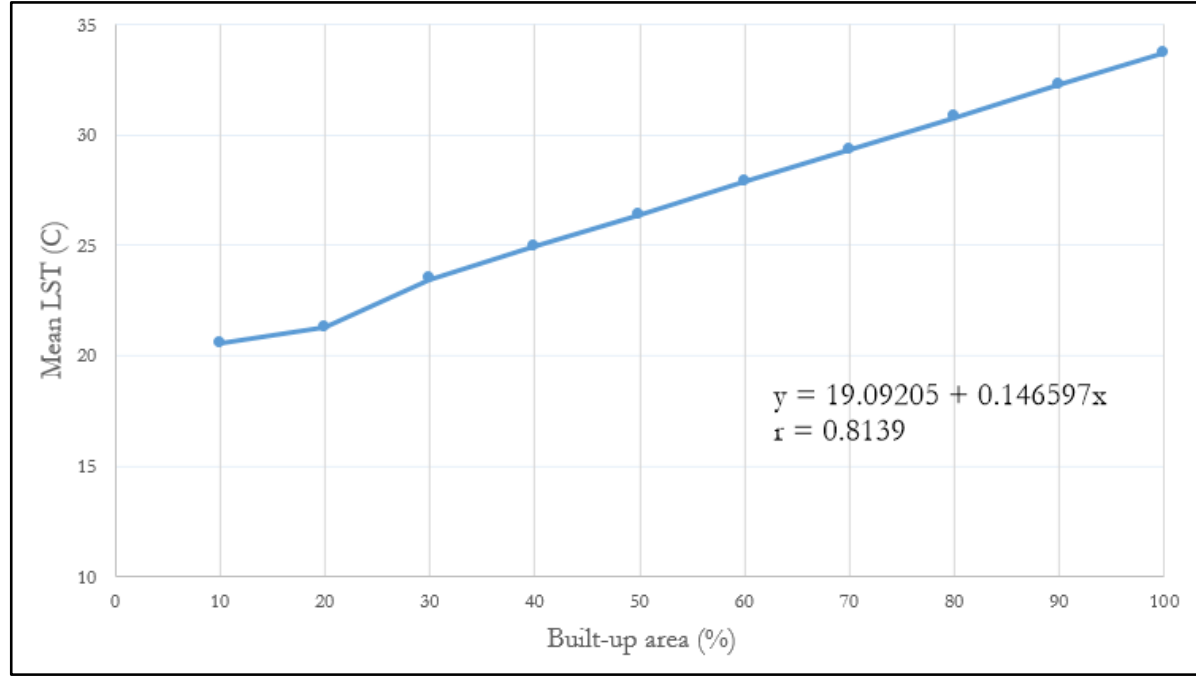

Fig. 5. Relationship between the built-up area (x) and mean LST (y).

Considering the ratio of changes in area of land use and the mean LST, all green areas of the city had a four-fold lower ratio than that of the community and building areas, with a difference in their mean LST of $2.76{ }^{\circ} \mathrm{C}$. Due to the increased community and building areas, the mean LST was increased by $3.32{ }^{\circ} \mathrm{C}$ (Fig. 6.).

\section{Discussion and Conclusion}

At an overall level of $90 \%$, the accuracy of the satellite imageries interpretation obtained from this study were considered reliable $[29-30,55,60]$. The data were in accordance with several research studies focusing on the overall accuracy of identifying land use categories using satellite imagery. For example, a study reported by English Bazar Municipality of Malda District [29] cited accuracy levels of $90.21 \%$ (2010) and $93.62 \%(2014)$. Another study regarding land use change in Tehran, Iran [30] indicated an overall accuracy of $93.41 \%$ in 2010; a third report from the north-western coastal desert of Egypt [62] cited an overall accuracy of $92.53 \%$ (1988), $93.77 \%$ (1999) and $97.30 \%$ (2011).

The research supports the hypothesis that LST increases with increased urbanization, and especially as a result of expansion of communities and buildings. This is in accordance with the findings of previous studies. e.g. $[1,4,8,63-64,65-72]$ showing that the highest temperatures are found at large (concrete) buildings such as shopping malls in particular as well as other large concrete constructions such as petrol stations, car parks, commercial stalls and community areas, all of which are distributed throughout the city centre and the old city. These buildings absorb and release thermal admittance, and also have a high reflection of the surface albedo $[3,13,39]$. [5] stated that the commercial sector was located at the city centre where there was a high density of buildings and populations. These areas have high mean temperatures compared to other areas of the city. Moreover, more energy is used for air conditioners and traffic in the city centre, which further increases the increased LST $[1,35]$. 


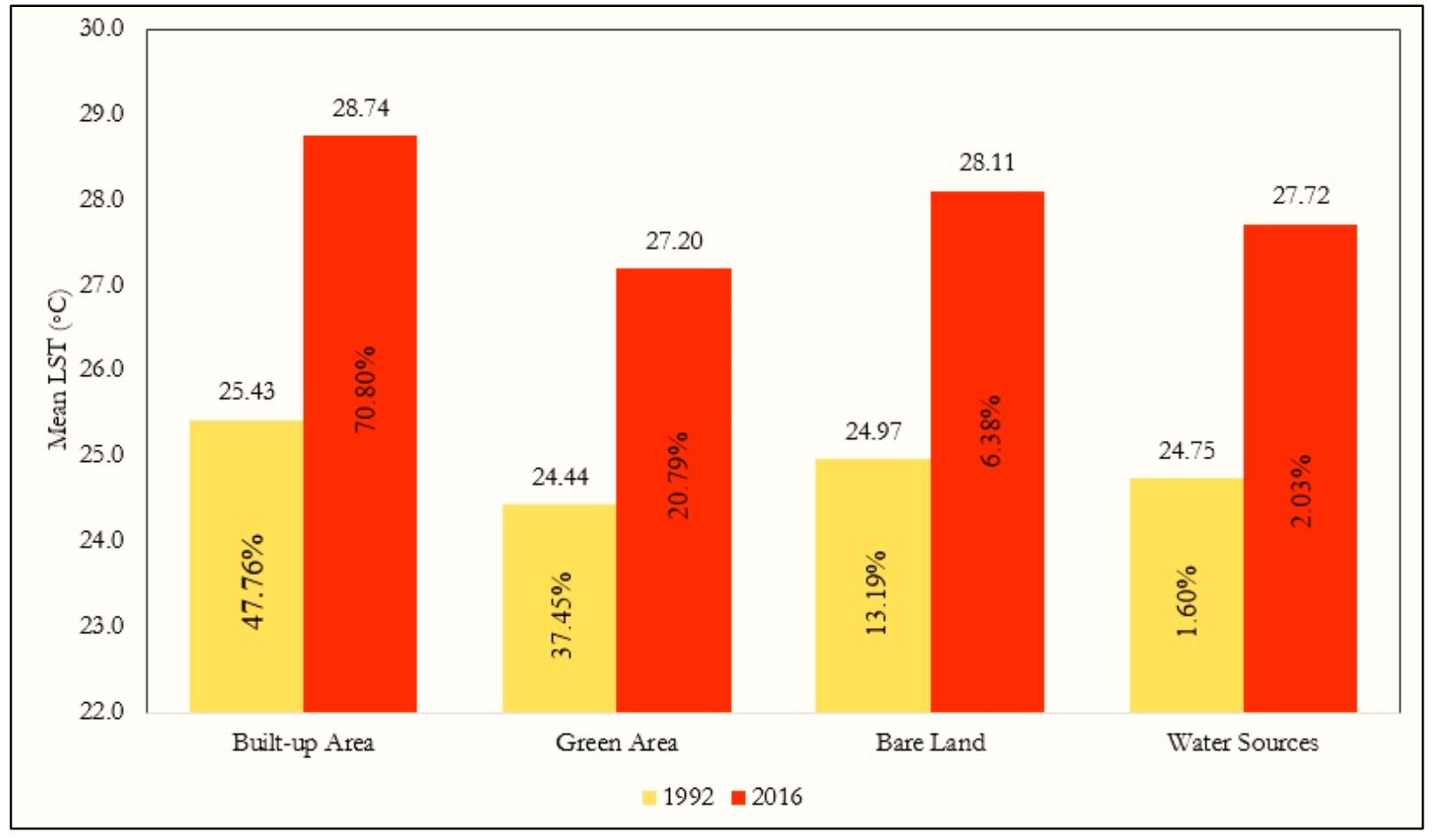

Fig. 6. Mean LST in each land use of Nakhon Ratchasima city in 1992 and 2016.

The results of LST in 1992 obtained from satellite image interpretation in this study was in accordance with the meteorological data for the same period [48]. The data revealed that in 1992, the average LST was $297.95 \mathrm{~K}\left(24.80^{\circ} \mathrm{C}\right)$ which was close to the satellite data interpretation projection of $297.89 \mathrm{~K}\left(24.74{ }^{\circ} \mathrm{C}\right)$. In May 2016, the average LST was $304.15 \mathrm{~K}\left(31^{\circ} \mathrm{C}\right)$, while interpretation of satellite image data projected 301.19 $\mathrm{K}\left(28.04{ }^{\circ} \mathrm{C}\right)$. The average LST from meteorological data was approximately $2.96 \mathrm{~K}\left(3^{\circ} \mathrm{C}\right)$ higher than the satellite image interpretation. This was due to higher summer temperatures [73]. The evaporation rate for the area on 9 May was higher $(6.2 \mathrm{~mm})$ than the average dry season evaporation rate $(5.6 \mathrm{~mm})$. The data from satellite was obtained during the day $(10: 31 \mathrm{am})$ when both temperature and evaporation rate were low. Soil moisture retained the temperature within the soil which reduced the temperature when the image was taken to below the average daytime LST [33-34]. The mean difference between LST obtained from satellite image interpretation and the actual temperature obtained from the area was found to be below $3 \mathrm{~K}$, which is considered acceptable according to many studies (e.g. [74-75]).

The lowest LST was found for the green areas because vegetation helps reduce the LST through evapotranspiration, increasing atmospheric and soil humidity $[9,36,76]$. Moreover, chlorophyll in plants reduced reflection, leading to a lower LST $[38,77]$. This study found a negative correlation between LST and the proportion of green area land use. When the proportion of green areas increased, LST decreased, which is in agreement with previous studies $[3,36,65,77]$ which associated reductions in LST with increasing ground covering vegetation [28, 32, 38, 76]. A previous study in Gabornone, Botswana reported the difference in the LST betwen green and city centre areas was about $2-4^{\circ} \mathrm{C}$ [29], whilst in Singapore where there was a higher difference of $4.01{ }^{\circ} \mathrm{C}$ between green areas and the city centre [74], reflecting the fact that Singapore city center has a higher density of buildings, both horizontally and vertically.

The proportion of bare land and water bodies are both low in Nakhon Ratchasima city and so they do not markedly affect the LST directly; however, this could change with increasing urbanization. When bare land is transformed to community settlements and buildings their reflectivity is dependent on the materials used to cover the bare land; building materials such as concrete have a high reflectance. Water sources have a lower mean LST due to the cooling effect of water evaporation from the water surface. Adjacent areas receive humid air, which lowers the LST [3, 76].

Urban planning should aim to reduce urban sprawl; land use planning is therefore crucial for managing city areas to control expansion and ensure appropriate land use. The provision of conserved and protected green areas to preserve the ecosystem would help control the city's LST. However, to specify the effect of land use change on temperature per unit is rather challenging due to the multiplicity of contributing factors, 
including climate, terrain, season, city pattern and city composition. Therefore, further research is needed to provide a more precise projections of how land use change might affect LST.

\section{Acknowledgements}

This research was supported by 90th Anniversary of Chulalongkorn University (Ratchadaphisek Somphot Endowment Fund). Additionally, the research was partially supported by the "Innovation in Increasing the Organic Carbon in Soil for Sustainable Agricultural Purpose in Saline Soil Areas: First Year Pilot Project at the Lam Ta Kong Watershed", Ratchadaphisek Somphot Endowment Fund (2014), Chulalongkorn University (CU-57-090-IC).

\section{References}

[1] D. Argüeso, J. P. Evans, L. Fita, and K. J. Bormann, "Temperature response to future urbanization and climate change," Climate Dynamics, vol. 42, no. 7-8, pp. 2183-2199, April 2014.

[2] A. Chudnovsky, E. Ben-Dor, and H. Saaroni, "Diurnal thermal behavior of selected urban objects using remote sensing measurements," Energy and Buildings, vol. 36, no. 11, pp. 1063-1074, November 2004.

[3] J. Voogt, "Urban heat islands: Hotter cities," American Institute of Biological Sciences, November 2004. Available: http://www.actionbioscience.org/environment/voogt.html

[4] American Forest. (2005). Urbanization affects [Online]. Available: https://www.americanforests.org/our-work/climate/ [Accessed: July 25, 2017]

[5] S. Wijitkosum and T. Sriburi, "Impact of urban expansion on water demand: The case study of Nakhon Ratchasima city, Lam Ta Kong Watershed," Nakhara: Journal of Environmental Design and Planning, vol. 4, pp. 69-88, 2008.

[6] Y. Ma and R. Xu, "Remote sensing monitoring and driving force analysis of urban expansion in Guangzhou City, China," Habitat International, vol. 34, pp. 228-235, 2010.

[7] S. Wijitkosum, "The settlement evolution of Nakhon Ratchasima city," Thailand Environmental Journal, vol. 14, no. 3, 2010.

[8] K. F. Ahmed, G. Wang, J. Silander, A. M. Wilson, J. M. Allen, R. Horton, and R. Anyah, "Statistical downscaling and bias correction of climate model outputs for climate change impact assessment in the U.S. northeast," Global and Planetary Change, vol. 100, pp. 320-332, January 2013.

[9] R. V. Pouyat, J. Aitkenhead-Peterson, and A. Volder, "Chemical, physical, and biological characteristics of urban soils," Urban Ecosystem Ecology, vol. 55, pp. 119-152, 2010.

[10] P. A. Mirzaei and F. Haghighat, "A novel approach to enhance outdoor air quality: Pedestrian ventilation system," Building and Environment, vol. 45, no. 7, pp. 1582-1593, July 2010.

[11] United Nations, "United Nations climate change conference," in PIF Congress Centre, Poznań International Fair, Poznań, Poland, 2008.

[12] United Nations Population Fund, "The state of the world population 2007," in UNFPA, New York, 2007.

[13] J. A. Voogt and T. R. Oke, "Thermal remote sensing of urban climates," Remote Sensing of Environment, vol. 86, no. 3, pp. 370-384, 2003.

[14] S. Stisen, K. H. Jensen, I. Sandholt, and D. I. F. Grimes, "A remote sensing driven distributed hydrological model of the Senegal River basin," Journal of Hydrology, vol. 354, pp. 101-10.8, 2008.

[15] R. Tang, Z. Li, and B. Tang, "An application of the Ts-VI triangle method with enhanced edges determination for evapotranspiration estimation from MODIS data in arid and semi-arid regions: Implementation and validation," Remote Sensing of Environment, vol. 114, no. 3, pp. 540-551, 2010.

[16] T. Laosuwan and S. Sangpradit, "Urban heat island monitoring and analysis by using integration of satellite data and knowledge based method," Int. J. Dev. Sustain., vol. 1, pp. 99-110, 2012.

[17] M. Srivanit and K. Hokao, "Effects of urban development and spatial characteristics on urban thermal environment in Chiang Mai Metropolitan, Thailand," Lowl. Technol. Int., vol. 14, pp. 9-22, 2012.

[18] Y.-A. Liou and S. K. Kar, "Evapotranspiration estimation with remote sensing and various surface energy balance algorithms-A review," Energies., vol. 7, no. 5, pp. 2821-2849, 2014.

[19] L. Song, W. P. Kustas, S. Liu, P. D. Colaizzi, H. Nieto, Z. Xu, Y. Ma, M. Li, T. Xu, N. Agam, J. A. Tolk, and S. R.. Evett, "Applications of a thermalbased two-source energy balance model using Priestley- 
Taylor approach for surface temperature partitioning under advective conditions," J. Hydrol., vol. 540, pp. 574-587, 2016.

[20] H. B. Erlandsen, I. Haddeland, L. M. Tallaksen, and J. Kristiansen, "The sensitivity of the terrestrial surface energy and water balance estimates in the WRF model to lower surface boundary representations: A South Norway case study," J. Hydrometeorol., vol. 18, no. 1, pp. 265-284, 2017.

[21] R. S. Padron, L. Gudmundsson, P. Greve, and S. I. Seneviratne, "Largescale controls of the surface water balance over land: insights from a systematic review and meta-analysis," Water Resour. Res., vol. 53, no. 11, pp. 9659-9678, 2017.

[22] P. KuipersMunneke, C. J. P. P. Smeets, C. H. Reijmer, J. Oerlemans, R. S. W. van de Wal, and M. R. van den Broeke, "The K-transect on the western Greenland Ice Sheet: Surface energy balance (20032016)," Arct. Antarct. Alp. Res., vol. 50, no. 1, p. e1420952, 2018.

[23] S. Jalan and K. Sharma, "Spatio-temporal assessment of land use/land cover dynamics and urban heat island of Jaipur city using satellite data," Int. Arch. Photogr. Remote Sens. Spat. Inform. Sci., vol. 40, no. 8, pp. 767, 2014.

[24] R. K. Mall, A. Gupta, and G. Sonkar, "Effect of climate change on agricultural crops," Current Developments in Biotechnology and Bioengineering, pp. 23-46., 2017.

[25] S. Wang, H. Zheng, S. Liu, Y. Miao, and J. Li, "Numerical study on the stomatal responses to dry-hot wind episodes and its effects on land atmosphere interactions," PLOS ONE, vol. 11, no. 9, p. e0162852, 2016.

[26] R. C. Estoque, Y. Murayama, and S. W. Myint., "Effects of landscape composition and pattern on land surface temperature: an urban heat island study in the megacities of Southeast Asia," Sci. Total Environ., vol. 577, pp. 349-359, 2017.

[27] W. Zhu, A. Lu, S. Jia, J. Yan, and R. Mahmood, "Retrievals of all-weather daytime air temperature from MODIS products," Remote Sens. Environ., vol. 189, pp. 152-163, 2017.

[28] Y. Naing, V. Nitivattananon, and O. Shipin, "Green roof retrofitting: Potential assessment in an academic campus," Engineering Journal, vol. 21, no. 7, pp. 57-74, Dec. 2017.

[29] S. Pal and S. Ziaul, "Detection of land use and land cover change and land surface temperature in English Bazar urban centre," The Egyptian Journal of Remote Sensing and Space Science, vol. 20, no. 1, pp. 125145, 2017.

[30] M. Bokaie, M. Kheirkhah Zarkesh, P. Daneshkar Arasteh, and A. Hosseini, "Assessment of urban heat island based on the relationship between land surface temperature and land use/land cover in Tehran," Sustainable Cities and Society, vol. 23, pp. 94-104, 2016.

[31] Copernicus Global Land Service. (2017). Land Surface Temperature and Surface Albedo. [Online]. Available: https://land.copernicus.eu/global/ [Accessed: August 17, 2017]

[32] P. Jonsson, "Vegetation as an urban climate control in the subtropical city of Gaborone, Botswana," International Journal of Climatology, vol. 24, no. 10, pp. 1307-1322, August 2004.

[33] S. N. Goward, "Thermal behavior of urban landscapes and the urban heat island," Physic. Geogr., vol. 2, pp. 19-33, 1981.

[34] W. Zhao and Z. L. Li, "Sensitivity study of soil moisture on the temporal evolution of surface temperature over bare surfaces," International Journal of Remote Sensing, vol. 34, no. 9-10, pp. 3314-3331, 2013.

[35] M. Santamouris, C. Cartalis, A. Synnefa, and D. Kolokotsa, "On the impact of urban heat island and global warming on the power demand and electricity consumption of buildings-A review," Energy and Buildings, vol. 98, pp. 119-124, July 2015.

[36] W. Yue, J. Xu, W. Tan, and L. Xu, "The relationship between land surface temperature and NDVI with remote sensing: application to Shanghai Landsat 7 ETM+ data," International Journal of Remote Sensing, vol. 28, no. 15, pp. 3205-3226, July 2007.

[37] X. Cao, A. Onishi, J. Chen, and H. Imura, "Quantifying the cool island intensity of urban parks using ASTER and IKONOS data," Landscape and Urban Planning, vol. 96, no. 4, pp. 224-231, June 2010.

[38] S. Hamada and T. Ohta, "Seasonal variations in the cooling effect of urban green areas on surrounding urban areas," Urban Forest and Urban Greening, vol. 9, no. 1, pp. 15-24, 2010.

[39] B. Tam, W. Gough, and T. Mohsin, "The impact of urbanization and the urban heat island effect on day to day temperature variation," Urban Climate, vol. 12, pp. 1-10, June 2015.

[40] X. L. Chen, H. M. Zhao, P. X. Li, and Z. Y. Yin, "Remote sensing image-based analysis of the relationship between urban heat island and land use/cover changes," Remote Sensing of Environment, vol. 104, no. 2, pp. 133-146, September 2006. 
[41] C. Keeratikasikorn and S. Bonafoni, "Urban heat island analysis over the land use zoning plan of Bangkok by means of Landsat 8 Imagery," Remote Sensing, vol. 10, no. 3, pp. 440, 2018.

[42] C. Keeratikasikorn and S. Bonafoni, "Satellite images and Gaussian parameterization for an extensive analysis of urban heat islands in Thailand," Remote Sensing, vol. 10, no. 5, pp. 665, 2018.

[43] Y. Jongtanom, C. Kositanont and S. Baulert, "Temporal variations of urban heat island intensity in three major cities, Thailand," Mod. Appl. Sci., vol. 5, pp. 105-110, 2011.

[44] S. D. Arifwidodo and T. Tanaka, "The characteristics of urban heat island in Bangkok, Thailand," Procedia Soc. Behav. Sci., vol. 195, pp. 423-428, 2015.

[45] S. Arifwidodo and O. Chandrasiri, "Urban heat island and household energy consumption in Bangkok, Thailand,” Energy Proc., vol. 79, pp. 189-194, 2015.

[46] M. Srivanit and K. Hokao, "Effects of urban development and spatial characteristics on urban thermal environment in Chiang Mai Metropolitan, Thailand," Lowl. Technol. Int., vol. 14, pp. 9-22, 2012.

[47] Thailand Environment Institute, "Environment Annual Report 2015," Thailand Environment Institute, Bangkok, Thailand, 2015.

[48] Thai Meteorological Department, "The meteorological data of Nakhon Ratchasima from Meteorological Station 1985-2014," Thai Meteorological Department, Bangkok, Thailand, 2017.

[49] J. R. Anderson, E. E. Hardy, J. T. Roach, and R. E. Witmer, "A land use and land cover classification system for use with remote sensor data," U.S. Geological Survey, U.S. Department of the Interior, 1976. [Online]. Available: http://pubs.er.usgs.gov/publication/pp964 [Accessed: August 18, 2016]

[50] J. Yang, J. Sun, Q. Ge, and X. Li,"Assessing the impacts of urbanization-associated green space on urban land surface temperature: A case study of Dalian, China," Urban Forestry \& Urban Greening, vol. 22, pp. 1-10, 2017.

[51] S. I. Toure, D. A. Stow, H. Shih, J. Weeks, and D. Lopez-Carr, "Land cover and land use change analysis using multi-spatial resolution data and object-based image analysis," Remote Sensing of Environment, vol. 210, pp. 259-268, 2018.

[52] N. Kabisch, P. Selsam, T. Kirsten, A. Lausch, and J. Bumberger, "A multi-sensor and multi-temporal remote sensing approach to detect land cover change dynamics in heterogeneous urban landscapes," Ecological Indicators, vol. 99, pp. 273-282, 2019.

[53] S. Thitawadee and M. Yoshihisa, "Urban growth prediction of special economic development zone in Mae Sot District, Thailand,” Engineering Journal, vol. 22, no. 3, pp. 269-277, Jun. 2018.

[54] Geo-Informatics and Space Technology Development Agency (Public Organization). (2019). GISTDA Satellite Data [Online]. Available: https://gistda.or.th/main/th/satellite [Accessed: March 10 2019]

[55] R. G. Pontius, "Quantification error versus location error in comparison of categorical maps," Photogrametric Engineering and Remote Sensing, vol. 66, no. 8, pp. 1011-1016, 2000.

[56] Nakhon Ratchasima City Municipality, "Geographic information systems data of Nakhon Ratchasima city," Nakhon Ratchasima City Municipality, Nakhon Ratchasima, Thailand. 2016

[57] J. C. Jimenez-Munoz, J. A. Sobrino, D. Skokovic, C. Mattat, and J. Cristobal, "Land surface temperature retrieval methods from Landsat-8 thermal infrared sensor data," IEEE Geoscience and Remote Sensing Letters, vol. 11, no. 10, pp. 1840-1843, April 2014.

[58] S. Bonafoni, G. Baldinelli, A. Rotili, and P. Verducci, "Albedo and surface temperature relation in urban areas: Analysis with different sensors," in 2017 Joint Urban Remote Sensing Event (JURSE), March 2017.

[59] G. Chander, B. Markham, and D. Helder, "Summary of current radiometric calibration coefficients for Landsat MSS, TM, ETM+, and EO-1 ALI sensors," Remote Sensing of Environment, vol. 113, no. 5, pp. 893-903, 2009.

[60] R. L. Lawrence and W. J. Ripple, "Calculating change curves for multi temporal satellite imagery: Mount St. Helens," Remote Sensing Environmental, vol. 67, no. 3, pp. 309-319, March 1999.

[61] H. Ren, C. Du, Q. Qin, R. Liu, J. Meng, and J. Li, "Atmospheric water vapor retrieval from Landsat 8 and its validation," in 2014 IEEE Geoscience and Remote Sensing Symposium, 2014, pp. 3045-3048.

[62] M. W. A. Halmy, "Land use/land cover change detection and prediction in the north-western coastal desert of Egypt using Markov-CA," Applied Geography, vol. 63, pp. 101-112, 2015.

[63] Y. Zhang and L. Sun., "Spatial-temporal impacts of urban land use land cover on land surface temperature: Case studies of two Canadian urban areas," International Journal of Applied Earth Observation and Geoinformation, vol. 75, pp. 171-181, 2019.

[64] X. Zhang, R. C. Estoque, and Y. Murayama, "An urban heat island study in Nanchang City, China based on land surface temperature and social-ecological variables," Sustainable Cities and Society, vol. 32, pp. $557-$ $568,2017$. 
[65] L. X. Qian, H. S. Cui, and J. Chang, "Impacts of land use and cover change on land surface temperature in the Zhujiang Delta," Pedosphere, vol. 16, no. 6, pp. 681-689, December 2006.

[66] C. L. Arnold and C. J. Gibbons, "Impervious surface coverage: The emergence of a key environmental indicator," Journal of the American Planning Association, vol. 62, no. 2, pp. 243-258, 1996.

[67] H. Xiao and Q. Weng, "The impact of land use and land cover changes on land surface temperature in a karst area of China," Journal of Environmental Management, vol. 85, no. 1, pp. 245-257, 2007.

[68] P. C. Sutton, S. J. Anderson, C. D. Elvidge, B. T. Tuttle, and T. Ghosh, "Paving the planet: Impervious surface as proxy measure of the human ecological footprint," Progress in Physical Geography: Earth and Environment, vol. 33, no. 4, pp. 510-527, 2009.

[69] X. Zhou and Y. C. Wang, "Dynamics of land surface temperature in response to land-use/cover change," Geographical Research, vol. 49, no. 1, pp. 23-36, 2011.

[70] M. O. Obiakor, C. D. Ezeonyejiaku, and T. C. Mogbo, "Effects of vegetated and synthetic (impervious) surfaces on the microclimate of urban area," J. Appl. Sci. Environ. Manage, vol. 16, pp. 85-94, 2012.

[71] B. Ahmed, M. Kamruzzaman, X. Zhu, M. S. Rahman, and K. Choi, "Simulating land cover changes and their impacts on land surface temperature in Dhaka, Bangladesh," Remote Sens., vol. 5, pp. 5969-5998, 2013.

[72] O. Van Nguyen, K. Kawamura, D. P. Trong, Z. Gong, and E. Suwandana, "Temporal change and its spatial variety on land surface temperature and land use changes in the Red River Delta, Vietnam, Using MODIS time-series imagery," Environ. Monit. Assess, vol. 187, pp. 464, 2015.

[73] M. L. Kueppers, M. A. Snyder, L. C. Sloan, and D. Cayan, "Seasonal temperature responses to land-use changein the western United States," Global Planet Change, vol. 60, pp. 250-264, 2008.

[74] D. C. Reuter, C. M. Richardson, F. A. Pellerano, J. R. Irons, R. G. Allen, M. Anderson, M. D. Jhabvala, A. W. Lunsford, M. Montanaro, R. L. Smith, Z. Tesfaye, and K. J. Thome, "The thermal infrared sensor (TIRS) on Landsat 8: Design overview and pre-launch characterization,” Remote Sens., vol. 7, pp. 11351153, 2015.

[75] D. Skoković, J. A. Sobrino, J. C. Jiménez-Muñoz, G. Sòria, Y. Julien, C. Mattar, and J. Cristóbal, "Calibration and validation of land surface temperature for Landsat8 TIRS Sensor," in LPVE (Land Product Validation and Evolution, ES A/ESRIN, Frascati, Italy, January 2014, pp. 28-30,

[76] N. H. Wong and C. Yu, "Study of green areas and urban heat island in a tropical city," Habitat International, vol. 29, no. 3, pp. 547-558, September 2005.

[77] Q. Weng, D. Lu, and J. Schubring, "Estimation of land surface temperature-vegetation abundance relationship for urban heat island studies," Remote Sensing of Environment, vol. 89, no. 4, pp. 467-483, February 2004. 